agriTECH, 41 (2) 2021, 172-183

\title{
Uji Kinerja dan Implementasi Aplikator Pupuk Cair Berbasis Variable Rate Application untuk Tanaman Kedelai (Glycine max)
}

\author{
Performance Test and The Implementation of Liquid Fertilizer Applicator based on Variable Rate Application (VRA) \\ for Soybean (Glycine max)
}

Miraj Fuadi*, Lilik Sutiarso, R. Radi

Departemen Teknik Pertanian dan Biosistem, Fakultas Teknologi Pertanian, Universitas Gadjah Mada

Jl. Flora No. 1, Bulaksumur, Yogyakarta 55281, Indonesia

*Penulis korespondensi: Miraj Fuadi; Email: mirajfuadi@gmail.com

Tanggal submisi: 13 Maret 2020; Tanggal revisi: 12 Mei 2020; Tanggal penerimaan: 9 Juni 2020

\begin{abstract}
ABSTRAK
Proses pemupukan merupakan salah satu tahapan yang sangat penting dalam meningkatkan kualitas dan kuatitas tanaman. Penggunaan pupuk kimia secara terus-menerus dengan dosis yang meningkat setiap tahunnya dapat mengganggu keseimbangan hara tanah. Oleh sebab itu dibutuhkan alat pemupuk berbasis variable rate application yang dapat mengatur dosis pupuk yang dibutuhkan oleh tanaman. Tujuan dari penelitian ini yaitu menguji kinerja alat pemupuk berbasis variable rate pada budidaya tanaman kedelai. Bahan yang digunakan adalah pupuk urea, SP-36, KCl, kacang kedelai (Glycine max) varietas Grobogan. Alat yang digunakan pada penelitian ini berupa rol meter, stopwatch, timbangan, multitester, penggaris, jangka sorong dan aplikator pemupuk. Kinerja alat dan dampaknya terhadap pertumbuhan kedelai diobservasi pada demplot seluas $36 \times 8 \mathrm{~m}^{2}$ yang dibagi menjadi 6 petak seluas $12 \times 4 \mathrm{~m}^{2}$ dan tiap petaknya diberikan kode petak A1 hingga A6. Hasil pengujian alat pemupuk di lapangan diperoleh kapasitas lapang efektif (KLE), kapasitas lapang teoritis (KLT), dan efisiensi lapang (Ef) berturut-turut sebesar $624 \mathrm{~m}^{2} / \mathrm{jam}, 864 \mathrm{~m}^{2} / \mathrm{jam}$, dan 72,27\%. Dari hasil analisis pertumbuhan tanaman menunjukkan bahwa secara statistik pemberian pupuk menggunakan aplikator tidak secara signifikan mempengaruhi parameter tinggi tanaman tetapi secara signifikan berpengaruh nyata terhadap diameter batang, jumlah daun dan coverage area. Meskipun demikian masih dijumpai ketidakseragaman produktivitas tanaman kedelai yang ditunjukkan dengan nilai signifikansi sebesar 0,028. Analisis regresi dengan variabel SP-36 (X2) terhadap produktivitas didapatkan fungsi $Y=-1,405 \cdot 10^{-4}+0,12 X_{2}-0,001 X_{2}^{2}$ dengan nilai $R^{2}$ sebesar 0,581 . Analisis regresi dengan variabel $\mathrm{KCl}$ (X3) terhadap produktivitas didapatkan fungsi $Y=-2,546.10^{-16}+0,053 X_{3}-2,063.10^{-4} X_{3}^{2}$ dengan nilai $R^{2}$ sebesar 0,701 .
\end{abstract}

Kata kunci: Uji kinerja; aplikator pupuk cair, variable rate, tanaman kedelai 


\begin{abstract}
Provision of fertilizer is crucial for improving the quality and quantity of the yield. However, using chemical fertilizer continuously with increasing doses can disrupt the balance of land nutrients. Therefore, it is necessary to use a variable-rate liquid fertilizer device to control fertilizer dose required by the plant. The research aimed to evaluate the variable-rate liquid fertilizer performance. The fertilizier applicator characterized by effective field capacity (EFC), theoretically field capacity (TFC) and field efficiency (FE). The materials used were fertilizier (Urea, Sp-36, KCL), Glycine max seeds Grobogan variety. While the equipments were a set of variable-rate liquid fertilizer applicator, scale, rollmeter, analytic balance, multitester, and calipers. To observe the plant responses by fertilizer applicator, a demplot of $36 \times 8 \mathrm{~m}^{2}$ was divided in 6 plots of $12 \times 4 \mathrm{~m}^{2}(\mathrm{~A} 1, \mathrm{~A} 2, \ldots \mathrm{A} 6)$. The evaluation showed respectively the EFC, TFC and FE were $624 \mathrm{~m}^{2} / \mathrm{h}, 864 \mathrm{~m}^{2} / \mathrm{h}$ and $72.27 \%$. The soybean growth showed that statistically the application of fertilizers using an applicator did not significantly affect plant height parameters but significantly affected the stem diameter, number of leaves and coverage area. Nevertheless, it was still found that soybean crop had different productivity, shown by a significance value of 0.028 . Regression analysis with the fertilizer SP-36 (X2) variable on productivity obtained the function $Y=-1.405 .10^{-4}+0.12 \mathrm{X}_{2}-0.001 \mathrm{X}_{2}{ }^{2}$ with an $\mathrm{R}^{2}$ of 0.581 . Regression analysis with the fertilizer $\mathrm{KCl}(\mathrm{X} 3)$ variable on productivity obtained the function $\mathrm{Y}=$ $-2.546 .10^{-16}+0.053 X_{3}-2.063 .10^{-4} X_{3}^{2}$ with an $R^{2}$ value of 0.701 .
\end{abstract}

Keywords: Performance test, variable-rate liquid fertilizer, soybean crops

\section{PENDAHULUAN}

Pertanian presisi merupakan sistem pertanian terpadu berbasis pada informasi dan produksi yang bertujuan meningkatkan efisiensi, produktivitas dan profitabilitas dari hulu ke hilir yang berkelanjutan, spesifik-lokasi serta meminimalkan dampak yang tidak diinginkan pada lingkungan (Whelan dan Taylor, 2013). Menurut Azis dkk. (2011), Sistem pertanian di Indonesia masih menerapkan teknologi perlakuan seragam atau URT (Uniform Rate Technology) saat proses pemupukan. Teknologi pemupukan ini memberikan perlakuan yang sama terhadap lahan pertanian tanpa memperhatikan kondisi tanah baik sifat fisik seperti tekstur dan struktur tanah maupun sifat kimia seperti kandungan hara/ nutrisi dan $\mathrm{pH}$ tanah.

Penggunaan pupuk kimia secara terus-menerus dengan dosis yang meningkat setiap tahunnya dapat menyebabkan tanah menjadi keras dan keseimbangan unsur hara tanah menjadi terganggu (Parnata, 2010). Pemberian pupuk pada budidaya kedelai masih berdasarkan rekomendasi yang bersifat umum yaitu 50 $100 \mathrm{~kg} \mathrm{KCl} / \mathrm{ha}+50-100 \mathrm{~kg} \mathrm{SP-36} / \mathrm{ha}+25-75 \mathrm{~kg}$ Urea/ha (Musaddad, 2008). Pertumbuhan tanaman tidak akan

Tabel 1. Rekomendasi N, P, dan K untuk tanaman kedelai pada setiap kelas hara tanah

\begin{tabular}{|c|c|c|c|c|}
\hline \multirow{2}{*}{$\begin{array}{l}\text { Kelas hara } \\
\text { tanah }\end{array}$} & \multirow{2}{*}{ Kategori } & \multirow{2}{*}{$\begin{array}{l}\text { Takaran pupuk } \\
(\mathrm{kg} / \mathrm{ha})\end{array}$} & \multicolumn{2}{|c|}{ Waktu pemberian } \\
\hline & & & 10 HST (\%) & 30 HST (\%) \\
\hline \multirow{3}{*}{$\mathrm{N}$} & Rendah & 174 urea & 70 & 30 \\
\hline & Sedang & 152 urea & 70 & 30 \\
\hline & Tinggi & 117 urea & 70 & 30 \\
\hline \multirow{3}{*}{$P$} & Rendah & 104 SP-36 & 100 & - \\
\hline & Sedang & 80 SP-36 & 100 & - \\
\hline & Tinggi & 40 SP-36 & 100 & - \\
\hline \multirow{3}{*}{ K } & Rendah & $210 \mathrm{KCl}$ & 70 & 30 \\
\hline & Sedang & $190 \mathrm{KCl}$ & 70 & 30 \\
\hline & Tinggi & $150 \mathrm{KCl}$ & 70 & 30 \\
\hline
\end{tabular}

Keterangan: HST: Hari setelah tanam

Sumber: Permadi dan Haryati, 2015 
optimal apabila kebutuhan unsur hara tidak tercapai (Azis dkk., 2011). Pemupukan berdasarkan kandungan Nitrogen (N), Fosfor (P), dan Kalium (K) tanah perlu dilakukan agar pemupukan lebih efisien dan kesuburan tanah tetap terjaga. Kebutuhan optimal hara N, P, dan $\mathrm{K}$ bagi tanaman kedelai tergantung pada hasil analisis tanah untuk mencapai hasil optimal yang dapat dilihat pada Tabel 1.

Sebagai komoditas tambahan yang diusahakan secara individual oleh petani, budidaya kedelai tidak dijumpai dalam hamparan yang luas, melainkan pada spot-spot luasan yang hanya puluhan hektar atau kurang tiap hamparannya (Subandi dkk., 2007). Dengan demikian, perlu penelitian lebih lanjut mengenai alat pemupuk presisi yang dapat diaplikasikan pada lahan yang sempit dan mengetahui pengaruh pemberian pupuk secara terkontrol terhadap produktivitas dan pertumbuhan tanaman kedelai.

\section{METODE PENELITIAN}

\section{Lokasi}

Penelitian ini dilakukan pada bulan Januari September 2019 terhitung dari survey dan sampling tanah, perancangan alat, uji coba alat, orientasi hingga pengujian NPK tanah, penanaman dan pengamatan pertumbuhan tanaman (Juli - September 2019) hingga analisa data. Lahan percobaan berlokasi di Ngemplak, Sleman, D.I Yogyakarta dengan luas $36 \times 8 \mathrm{~m}^{2}$. Pada lahan tersebut dibagi menjadi 6 petak seluas $12 \times 4$ $\mathrm{m}^{2}$ dan tiap petaknya diberikan kode petak A1 hingga A6. Setiap petak ditanami kedelai dengan cara ditugal dan dengan jarak tanam $40 \mathrm{~cm} \times 20 \mathrm{~cm}$. Berdasarkan penelitian yang dilakukan oleh Srihartanto dkk. (2015), jarak tanam $40 \mathrm{~cm} \times 20 \mathrm{~cm}$ merupakan jarak tanam terbaik untuk meningkatkan produktivitas kedelai di DI Yogyakarta.

\section{Bahan dan Alat}

Bahan yang digunakan adalah pupuk urea, SP-36, $\mathrm{KCl}$, kacang kedelai (Glycine max) varietas Grobogan. Alat yang digunakan pada penelitian ini berupa rol meter, stopwatch, timbangan, multitester, penggaris, jangka sorong dan aplikator pemupuk. Aplikator ini dirancang untuk dioperasikan oleh satu orang seperti yang ditunjukkan pada Gambar 1.

Komponen aplikator terdiri dari kerangka, roda, control box, motor sprayer, motor gearbox, pegangan, baterai aki $12 \mathrm{~V}$, switch, pengukur tekanan, tangki dan tank bracket. Aplikator dijalankan menggunakan motor gearbox $12 \mathrm{~V}$ yang dipasang di kedua roda belakang, sedangkan pupuk cair dalam tangki disuplai dengan motor sprayer $12 \mathrm{~V}$ DC yang dipasang di bagian tank bracket. Kecepatan aplikator dan pengeluaran pupuk cair diatur dengan memutar dimmer controller di control box. Berdasarkan hasil uji laboratorium, debit yang dapat dicapai oleh motor sprayer berkisar 192,08 - 734,17 mL/menit dan kecepatan aplikator yang dapat ditempuh berkisar 0,08-0,81 m/s. Kombinasi kecepatan $0,2 \mathrm{~m} / \mathrm{s}$ dengan rekomendasi nilai dimmer level motor sprayer memperoleh nilai koefisien variasi berkisar 4,54- 6,45\% untuk pupuk urea dan 2,71 $4,45 \%$ untuk pupuk KCl. Nilai error yang didapat tidak lebih dari 7,82 \% (Fuadi dkk., 2019).

\section{Uji Kinerja Alat Pemupuk di Lapangan}

Untuk mengevaluasi kemampuan kerja aplikator pupuk cair yang dioperasikan pada kondisi yang optimal. Pengukuran parameter uji dilakukan setelah aplikator siap dioperasikan. Beberapa parameter uji yang diukur adalah lebar kerja efektif pipa pemupuk, kapasitas lapang efektif, kecepatan kerja aktual, waktu total operasi, waktu kerja tidak efektif, dan efisiensi lapang. Skema uji kinerja di lapangan dapat dilihat pada Gambar 2.

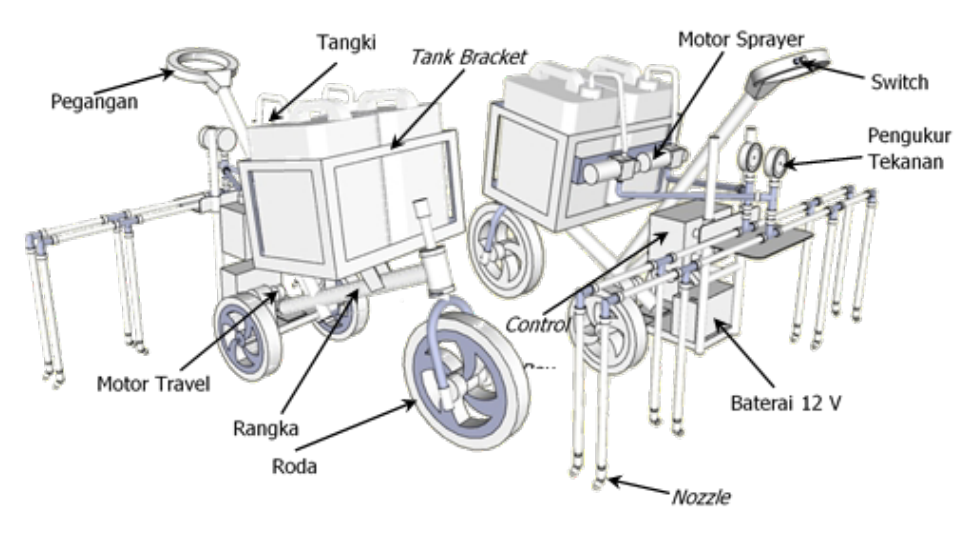

Gambar 1. Aplikator pupuk terkontrol atau Variable-Rate Application (VRA) 


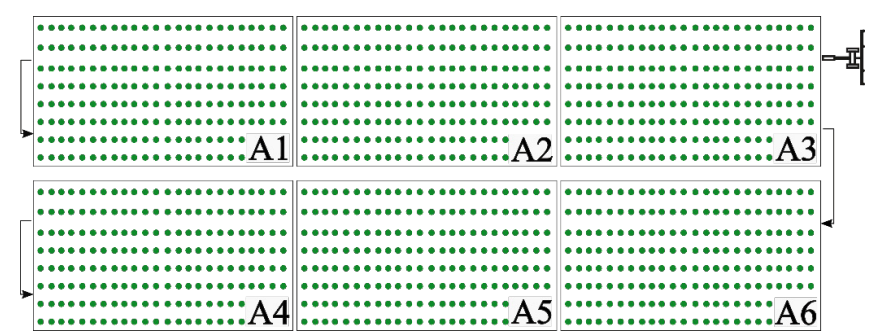

Gambar 2. Skema pemupukan

\section{Cara Perhitungan}

Kapasitas lapang efektif (KLE, $\mathrm{m}^{2} / \mathrm{jam}$ ) dihitung dengan Persamaan 1. Kapasitas lapang teoritis dihitung dengan Persamaan 2, dan efisiensi lapang pemupukan (Ef, \%) dihitung dengan Persamaan 3.

$$
K L E=\frac{A}{t}
$$

Dimana: $K L E=$ kapasitas lapang efektif $\left(\mathrm{m}^{2} / \mathrm{jam}\right), A=$ luas lahan terpupuk $\left(\mathrm{m}^{2}\right)$, dan $t=$ waktu selama operasi (waktu lapang total) (jam).

$$
K L T=3600 \times W t \times V t
$$

Dimana: $K L T=$ kapasitas lapang teoritis, $\left(\mathrm{m}^{2} / \mathrm{jam}\right)$, $W t=$ lebar kerja teoritis alat pemupuk $(\mathrm{m})$, dan $V t=$ kecepatan kerja teoritis ( $\mathrm{m} /$ detik).

$$
E f=\left(\frac{K L E}{K L T}\right) \times 100 \%
$$

Dimana: $E f=$ efisiensi lapang pemupukan (\%), $K L E=$ kapasitas lapang efektif $\left(\mathrm{m}^{2} / \mathrm{jam}\right)$ dan $K L T=$ kapasitas lapang teoritis $\left(\mathrm{m}^{2} / \mathrm{jam}\right)$.

\section{Uji Kandungan Hara Tanah}

Sampel tanah diambil di lahan uji yang terletak di Ngemplak, Sleman, D.I. Yogyakarta. Penentuan NPKtanah dilakukan melalui uji laboratorium untuk mendapatkan kandungan N-tersedia, P-tersedia, K-tersedia, kapasitas pertukaran kation (KPK) dan tekstur tanah. Pengambilan sampel tanah dilakukan secara komposit pada kedalaman $0-20 \mathrm{~cm}$ dengan jumlah 1 sampel untuk setiap petaknya. Pengujian kandungan tanah dilakukan di Laboratorium Tanah, Fakultas Pertanian, Universitas Pembangunan Nasional Veteran Yogyakarta (UPNVY). Hasil dari uji laboratorium selanjutnya diklasifikasikan berdasarkan nilai pada Tabel 2. Pemupukan dilakukan menggunakan 2 cara yaitu menggunakan aplikator (Urea dan $\mathrm{KCl}$ ) dan manual (SP-36) dengan jumlah dosis sesuai hasil kandungan NPK tanah. Pemupukan SP-36 dilakukan manual dengan cara menaburi pupuk di dekat perakaran kedelai.

\section{Pertumbuhan Kedelai}

Pengamatan pertumbuhan tanaman dalam penelitian ini meliputi tinggi tanaman, jumlah daun, diameter batang, dan coverage area yang diambil diambil setiap 7 hari sekali. Pemberian air irigasi dilakukan 3 kali yaitu sehari sebelum tanam, setelah pemupukan 10 HST dan 30 HST. Tinggi tanaman diukur dari pangkal tanaman pada permukaan tanah sampai pada titik tumbuh tertinggi. Jumlah daun dihitung setiap minggu dengan menghitung semua daun mulai dari daun unifoliet sampai daun yang sudah terbuka. Pengamatan coverage area pada tanaman kedelai menggunakan penggaris atau meteran yang diukur dari ujung terluar daun hingga batang tanaman secara tegak lurus. Pengukuran diameter batang menggunakan jangka sorong. Pengamatan tinggi tanaman dan jumlah daun dimulai pada saat tanaman berumur 14 HST hingga 63 HST. Pengukuran produktivitas dilakukan dengan cara memanen kedelai pada luas petak $2 \mathrm{~m} \times 0,8 \mathrm{~m}$ dan dilakukan 3 kali ulangan pada setiap petaknya. Kedelai yang sudah dipanen selanjutnya dijemur untuk memisahkan antara kulit dan biji kedelai. Biji kedelai kemudian ditimbang dan dikonversi ke ton/ha.

Data pertumbuhan tanaman yang diperoleh dianalisis menggunakan ANOVA satu arah untuk mengetahui beda nyata antara tiap petak pada beberapa parameter pertumbuhan dan hasil tanaman

Tabel 2. Klasifikasi kandungan nitrogen $(\mathrm{N})$, phosfor $(\mathrm{P})$, dan kalium $(\mathrm{K})$ yang tersedia dalam tanah

\begin{tabular}{ccccccc}
\hline \multirow{2}{*}{$\begin{array}{c}\text { Kelas hara } \\
\text { tanah }\end{array}$} & Satuan & \multicolumn{4}{c}{ Klasifikasi } & \\
\cline { 3 - 5 } & & Rendah & Sedang & Tinggi & $\begin{array}{c}\text { Sangat } \\
\text { tinggi }\end{array}$ & Sumber \\
\hline $\mathrm{N}$ & $\%$ & $0,1-0,2$ & $0,21-0,5$ & $0,51-0,75$ & $>0,75$ & Yamani, 2012 \\
$\mathrm{P}$ & $\mathrm{ppm}$ & $<10$ & $10-25$ & $25-50$ & $>50$ & Horneck dkk., 2011 \\
$\mathrm{K}$ & $\mathrm{me} / 100 \mathrm{~g}$ & $<0,4$ & $0,4-0,6$ & $0,6-2,0$ & $>2,0$ & Horneck dkk., 2011 \\
\hline
\end{tabular}


Tabel 3. Hasil pengujian sampel tanah

\begin{tabular}{cccccccc}
\hline & \multicolumn{3}{c}{ Sifat kimia tanah } & \multicolumn{3}{c}{ Sifat fisik tanah } \\
\cline { 2 - 8 } Petak & $\mathrm{N}(\%)$ & $\begin{array}{c}\mathrm{P} \\
(\mathrm{ppm})\end{array}$ & $\begin{array}{c}\mathrm{K} \\
(\mathrm{me} / 100 \mathrm{~g})\end{array}$ & $\begin{array}{c}\text { KPK }(\mathrm{me} / 100 \\
\mathrm{g})\end{array}$ & $\begin{array}{c}\text { Debu } \\
(\%)\end{array}$ & $\begin{array}{c}\text { Lempung } \\
(\%)\end{array}$ & $\begin{array}{c}\text { Pasir } \\
(\%)\end{array}$ \\
\hline A1 & 0,006 & 11,29 & 0,53 & 5,29 & 18,80 & 3,80 & 77,40 \\
A2 & 0,008 & 16,43 & 1,08 & 6,52 & 16,20 & 12,40 & 71,40 \\
A3 & 0,010 & 30,22 & 1,20 & 8,61 & 11,70 & 10,80 & 77,50 \\
A4 & 0,007 & 10,43 & 0,54 & 4,97 & 9,20 & 8,60 & 82,20 \\
A5 & 0,005 & 13,97 & 0,64 & 7,25 & 15,30 & 9,80 & 74,90 \\
A6 & 0,008 & 38,02 & 0,63 & 7,15 & 18,10 & 9,60 & 72,30 \\
\hline
\end{tabular}

kedelai. Apabila ada pengaruh nyata dilanjutkan pengujian menggunakan metode DMRT (Duncan Multiple Range Test) dengan taraf signifikansi 5\%. Prediksi produktivitas kedelai dilakukan menggunakan uji regresi linier berganda menggunakan software IBM SPSS Modeler 16.0.

\section{HASIL DAN PEMBAHASAN}

\section{Hasil Uji Kinerja Aplikator Pemupuk di Lapangan}

Pengujian aplikator pemupuk di lapangan didasarkan atas hasil pengujian $\mathrm{N}, \mathrm{P}$, dan $\mathrm{K}$ tanah sebelum tanam. Berdasarkan hasil uji lab tanah yang disajikan pada Tabel 3, tekstur tanah pada seluruh petak didominasi oleh pasiran, dengan nilai KPK yang diperoleh rendah berkisar 4,97-7,25 me/100 g. Nilai $\mathrm{N}$, P, dan $\mathrm{K}$ yang diperoleh kemudian diklasifikasikan berdasarkan kelas status hara rendah, sedang, dan tinggi dengan acuan Tabel 2 .

Hasil dari klasifikasi kelas N, P, dan K tanah ditampilkan pada Gambar 3. Pada Gambar 3(a), menunjukkan bahwa kandungan $\mathrm{N}$-tersedia pada seluruh petak rendah, sedangkan pada pada Gambar 3(b) dan 3(c) menunjukkan bahwa kandungan P-tersedia dan K-tersedia berada pada kategori sedang dan tinggi. Menurut Rahutomo dan Ginting (2018), tekstur tanah yang didominasi pasir, tanah yang masam, kandungan bahan organik rendah, dan KPK yang rendah akan berakibat pada berkurangnya kemampuan tanah menyerap hara dalam bentuk kation.

Pengujian di lapangan dilakukan saat tanaman berumur 10 HST. Kecepatan aplikator disesuaikan terlebih dahulu agar mendapatkan kecepatan sebesar 0,2 $\mathrm{m} / \mathrm{s}$. Berdasarkan hasil pengujian di lapangan diperoleh nilai $\Delta \mathrm{V}$ pemupukan urea dan $\mathrm{KCl}$ serta nilai efisiensi lapang yang tunjukan oleh Tabel $4-$ Tabel 6 . Pada tabel tersebut menunjukkan bahwa nilai $\Delta \mathrm{V}$ pemupukan urea berkisar 649 - $1150 \mathrm{~mL}$ dan pemupukan $\mathrm{KCl}$ berkisar $965-1219 \mathrm{~mL}$ dengan nilai efisiensi lapang pemupukan sebesar $72,27 \%$.

Nilai $\Delta \mathrm{V}$ yang diperoleh dari uji lapangan lebih tinggi dibandingkan dengan hasil uji lab dikarenakan permukaan tanah yang tidak rata serta luas permukaan roda yang kecil menyulitkan aplikator untuk bergerak seperti yang ditunjukan oleh Gambar 4a. Selain itu

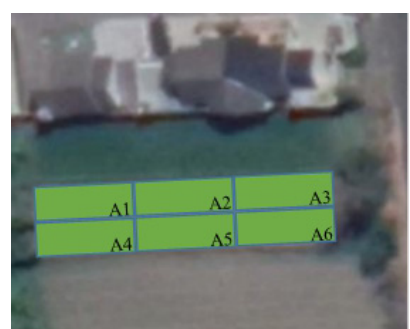

(a)

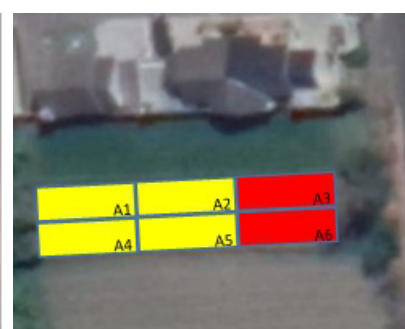

(b)

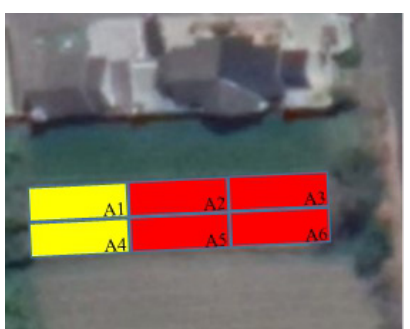

(c)
Keterangan:

- Tinggi

Sedang

Rendah

Keterangan:

- Tinggi

Sedang

Rendah

Gambar 3. Hasil uji laboratorium (a) kandungan N-tersedia tanah, (b) kandungan P-tersedia, dan (c) kandungan K-tersedia tanah 
Tabel 4. Selisih volume pemupukan urea 10 HST

\begin{tabular}{ccccccr}
\hline Petak & Kategori & $\begin{array}{c}\text { Debit } \\
\text { observasi } \\
(\mathrm{mL} / \mathrm{menit})\end{array}$ & $\begin{array}{c}\text { Rekomendasi } \\
\text { pemupukan } \\
(\mathrm{mL})\end{array}$ & Waktu (s) & $\begin{array}{c}\text { Volume } \\
\text { observasi } \\
(\mathrm{mL})\end{array}$ & \multicolumn{1}{c}{$\begin{array}{c}\Delta \mathrm{V} \\
(\mathrm{mL})\end{array}$} \\
\hline A1 & Rendah & 710 & 6162,2 & 143,9 & 6811,27 & 649,07 \\
A2 & Rendah & 710 & 6162,2 & 144,6 & 6844,40 & 682,20 \\
A3 & Rendah & 710 & 6162,2 & 152,6 & 7223,07 & 1060,87 \\
A4 & Rendah & 710 & 6162,2 & 148,7 & 7038,47 & 876,27 \\
A5 & Rendah & 710 & 6162,2 & 151,1 & 7147,33 & 985,13 \\
A6 & Rendah & 710 & 6162,2 & 154,5 & 7313,00 & 1150,80 \\
\hline
\end{tabular}

Tabel 5. Selisih volume pemupukan KCl 10 HST

\begin{tabular}{ccccccc}
\hline Petak & Kategori & $\begin{array}{c}\text { Debit } \\
\text { observasi } \\
(\mathrm{mL} / \mathrm{menit})\end{array}$ & $\begin{array}{c}\text { Rekomendasi } \\
\text { pemupukan } \\
(\mathrm{mL})\end{array}$ & Waktu $(\mathrm{s})$ & $\begin{array}{c}\text { Volume } \\
\text { observasi } \\
(\mathrm{mL})\end{array}$ & $\begin{array}{c}\Delta \mathrm{V} \\
(\mathrm{mL})\end{array}$ \\
\hline A1 & Sedang & 640 & 5174,5 & 143,9 & 6139,73 & 965,23 \\
A2 & Tinggi & 515 & 4085,1 & 144,6 & 4964,60 & 879,50 \\
A3 & Tinggi & 515 & 4085,1 & 152,6 & 5239,27 & 1154,17 \\
A4 & Sedang & 640 & 5174,5 & 148,7 & 6344,53 & 1170,03 \\
A5 & Tinggi & 515 & 4085,1 & 151,1 & 5184,33 & 1099,23 \\
A6 & Tinggi & 515 & 4085,1 & 154,5 & 5304,50 & 1219,40 \\
\hline
\end{tabular}

Tabel 6. Hasil uji lapangan

\begin{tabular}{ccccccc}
\hline $\begin{array}{c}\mathrm{A} \\
\left(\mathrm{m}^{2}\right)\end{array}$ & $\begin{array}{c}\mathrm{t} \\
(\mathrm{jam})\end{array}$ & $\begin{array}{c}\mathrm{Vt} \\
(\mathrm{m} / \mathrm{s})\end{array}$ & $\begin{array}{c}\mathrm{Wt} \\
(\mathrm{m})\end{array}$ & $\begin{array}{c}\mathrm{KLE} \\
\left(\mathrm{m}^{2} / \mathrm{jam}\right)\end{array}$ & $\begin{array}{c}\mathrm{KLT} \\
\left(\mathrm{m}^{2} / \mathrm{jam}\right)\end{array}$ & $\begin{array}{c}E f \\
(\%)\end{array}$ \\
\hline 201,6 & 0,32 & 0,2 & 1,2 & 624 & 864 & 72,27 \\
\hline
\end{tabular}

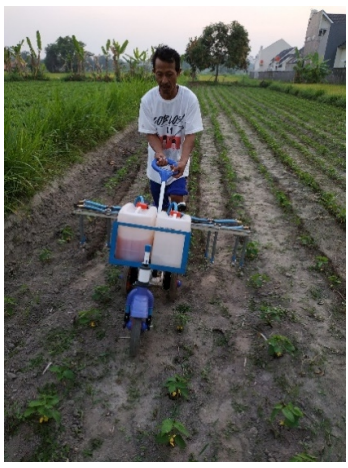

(a)

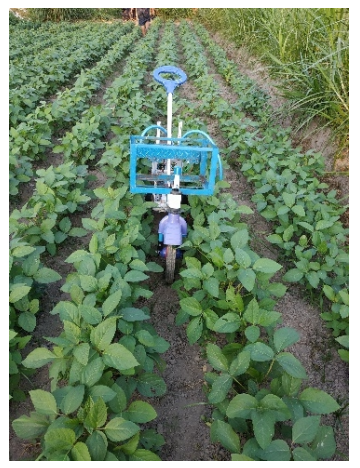

(b)
Gambar 4. (a) Proses pemupukan 10 HST (b) Kondisi lahan saat 30 HST

karena kapasitas tangki yang kecil sehingga harus melakukan beberapa kali pengisian tangki. Pengisian ulang yang membutuhkan cukup banyak waktu ini mempengaruhi nilai Ef. Kondisi tanaman pada $30 \mathrm{HST}$ dapat kita lihat pada Gambar 4b, dimana roda dan dudukan tangki mengenai tanaman kedelai, dan apabila dipaksakan akan merusak tanaman. Sehingga pada pemupukan 30 HST dilakukan secara manual karena risiko terkena bunga yang akan berpengaruh terhadap hasil panen kedelai. Pemberian air dilakukan setelah pemupukan melalui irigasi atau sumur dengan bantuan mesin diesel.

\section{Pengaruh Pemupukan terhadap Pertumbuhan Tanaman Kedelai}

\section{Tinggi tanaman}

Berdasarkan hasil uji Duncan (Tabel 7) menunjukkan bahwa tinggi tanaman pada usia 14 HST 
Tabel 7. Rata-rata tinggi tanaman pada berbagai umur pengamatan

\begin{tabular}{ccccccccc}
\hline \multirow{2}{*}{ Petak } & \multicolumn{7}{c}{ Tinggi tanaman pada umur (HST) } \\
\cline { 2 - 8 } & 14 & 21 & 28 & 35 & 42 & 49 & 56 & 63 \\
\hline A1 & $10,8^{\mathrm{a}}$ & $16,6^{\mathrm{a}}$ & $24,2^{\mathrm{a}}$ & $29,65^{\mathrm{a}}$ & $32,3^{\mathrm{a}}$ & $33,0^{\mathrm{a}}$ & $33,2^{\mathrm{a}}$ & $33,6^{\mathrm{a}}$ \\
A2 & $11,7^{\mathrm{a}}$ & $17,2^{\mathrm{a}}$ & $24,7^{\mathrm{a}}$ & $31,52^{\mathrm{a}}$ & $38,0^{\mathrm{a}}$ & $39,0^{\mathrm{a}}$ & $39,1^{\mathrm{a}}$ & $39,4^{\mathrm{a}}$ \\
A3 & $10,6^{\mathrm{a}}$ & $16,4^{\mathrm{a}}$ & $23,6^{\mathrm{a}}$ & $29,07^{\mathrm{a}}$ & $36,5^{\mathrm{a}}$ & $38,0^{\mathrm{a}}$ & $38,3^{\mathrm{a}}$ & $39,1^{\mathrm{a}}$ \\
A4 & $8,6^{\mathrm{a}}$ & $14,9^{\mathrm{a}}$ & $21,6^{\mathrm{a}}$ & $29,48^{\mathrm{a}}$ & $35,9^{\mathrm{a}}$ & $36,8^{\mathrm{a}}$ & $37,0^{\mathrm{a}}$ & $37,3^{\mathrm{a}}$ \\
A5 & $10,4^{\mathrm{a}}$ & $15,5^{\mathrm{a}}$ & $22,4^{\mathrm{a}}$ & $29,15^{\mathrm{a}}$ & $34,1^{\mathrm{a}}$ & $35,9^{\mathrm{a}}$ & $36,1^{\mathrm{a}}$ & $36,5^{\mathrm{a}}$ \\
A6 & $10,7^{\mathrm{a}}$ & $15,3^{\mathrm{a}}$ & $21,4^{\mathrm{a}}$ & $27,17^{\mathrm{a}}$ & $30,3^{\mathrm{a}}$ & $33,9^{\mathrm{a}}$ & $34,1^{\mathrm{a}}$ & $34,3^{\mathrm{a}}$ \\
Sig. & 0,075 & 0,247 & 0,579 & 0,555 & 0,291 & 0,446 & 0,435 & 0,422 \\
CV & 9,79 & 5,72 & 6 & 4,75 & 8,26 & 6,33 & 6,4 & 6,48 \\
\hline
\end{tabular}

Keterangan: Angka yang diikuti oleh huruf yang sama (huruf kecil vertikal) berbeda tidak nyata pada taraf 5\% (Uji DMRT).

hingga 63 HST pada seluruh petak tidak berpengaruh nyata. Hal ini diduga terjadi karena dosis pupuk urea yang yang seragam. Menurut Wahyudin dkk. (2015), nitrogen merupakan salah satu unsur hara makro yang berperan sebagai bahan dasar pembentukan klorofil dan penyusunan protein bagi tanaman yang diperlukan dalam pembentukan dan pertumbuhan vegetatif tanaman. Pernyataan tersebut sesuai dengan kandungan $\mathrm{N}$-tersedia tanah yang seragam pada seluruh petak, sehingga pertumbuhan tinggi tanaman tidak menunjukan perbedaan yang siginifikan untuk setiap petaknya.

\section{Jumlah daun}

Pemberian pupuk urea pada 10 HST dan 30 HST dengan dosis yang sama pada tiap petaknya menunjukkan pertumbuhan yang seragam pada 21 HST - 49 HST (Tabel 8). Sedangkan jumlah daun pada usia 14 HST dan 56 HST menunjukkan hasil yang berbeda nyata terhadap variasi pemupukan antar petak. Hal ini dikarenakan pada usia 0 -14 HST, kedelai belum menunjukkan pengaruh terhadap pemberian pupuk saat 10 HST sehingga jumlah daun antar petak menunjukkan nilai yang berbeda nyata dengan nilai signifikansi $<0,05$. Selain itu perbedaan nyata pada usia 56 HST diduga karena faktor lingkungan seperti penyakit dan hama.

Hama dan penyakit pada tanaman kedelai sudah mulai terlihat pada usia 28 HST. Kedelai merupakan tanaman yang paling besar menghadapi ancaman serangan hama dan/atau penyakit sejak fase bibit sampai dengan pengisian polong (Marwoto, 1999). Penyakit yang terpenting pada kedelai adalah karat daun. Penyakit sangat merusak bila menyerang mulai tanaman berumur 50 hari atau lebih muda. Selain menanam varietas toleran, pengendalian dengan fungisida dapat dianjurkan bila penyakit belum berkembang, dan tanaman masih berumur kurang dari 60 hari (Sumarno, 1995).

\section{Coverage area}

Pengukuran luas cakupan tanaman atau coverage area dilakukan untuk melihat kerapatan antar tanaman. Pada Gambar 5, dapat kita lihat grafik pertumbuhan coverage area kedelai pada seluruh petak meningkat setiap minggunya. Rata-rata teringgi coverage area pada usia 42 HST ditunjukan oleh petak A3 sebesar 2097, $56 \mathrm{~cm}^{2}$. Berdasarkan hasil uji Duncan yang menunjukkan bahwa parameter coverage area pada usia 21 HST - 42 HST menunjukkan hasil yang tidak berbeda nyata terhadap perlakuan variasi pemupukan antar petak (Tabel 9). Hal tersebut terjadi karena pada usia 21 - 42 HST rata-rata tinggi tanaman dan jumlah daun pada setiap petak tidak menunjukkan hasil yang berbeda nyata.

\section{Diameter batang}

Berdasarkan hasil uji Duncan (Tabel 10) menunjukkan bahwa perkembangan diameter batang pada umur 21 HST menunjukkan hasil yang berbeda nyata terhadap perlakuan variasi pemupukan antar petak tetapi tidak berbeda nyata pada usia 28 HST hingga 63 HST. Sama halnya seperti parameter tinggi tanaman dan jumlah daun, perkembangan diameter batang dipengaruhi oleh kandungan nitrogen dalam tanah. Apabila dilihat pada hasil kandungan $\mathrm{N}$ tanah pada setiap petak yang seragam, seharusnya diameter 
Tabel 8. Rata-rata jumlah daun pada berbagai umur pengamatan

\begin{tabular}{ccccccccc}
\hline \multirow{2}{*}{ Petak } & \multicolumn{7}{c}{ Jumlah daun pada umur (HST) } \\
\cline { 2 - 8 } & 14 & 21 & 28 & 35 & 42 & 49 & 56 & 63 \\
\hline A1 & $9,7^{\mathrm{b}}$ & $11,0^{\mathrm{a}}$ & $23,0^{\mathrm{a}}$ & $32,5^{\mathrm{a}}$ & $39,5^{\mathrm{a}}$ & $38,0^{\mathrm{a}}$ & $35,3^{\mathrm{ab}}$ & $30,0^{\mathrm{a}}$ \\
A2 & $8,0^{\mathrm{a}}$ & $11,0^{\mathrm{a}}$ & $20,5^{\mathrm{a}}$ & $27,5^{\mathrm{a}}$ & $37,8^{\mathrm{a}}$ & $35,8^{\mathrm{a}}$ & $33,5^{\mathrm{ab}}$ & $28,7^{\mathrm{a}}$ \\
A3 & $7,5^{\mathrm{a}}$ & $12,0^{\mathrm{a}}$ & $21,5^{\mathrm{a}}$ & $35,2^{\mathrm{a}}$ & $38,7^{\mathrm{a}}$ & $38,2^{\mathrm{a}}$ & $38,3^{\mathrm{b}}$ & $38,8^{\mathrm{a}}$ \\
A4 & $10,0^{\mathrm{b}}$ & $10,5^{\mathrm{a}}$ & $18,3^{\mathrm{a}}$ & $27,7^{\mathrm{a}}$ & $32,7^{\mathrm{a}}$ & $30,7^{\mathrm{a}}$ & $27,8^{\mathrm{a}}$ & $25,7^{\mathrm{a}}$ \\
A5 & $10,0^{\mathrm{b}}$ & $11,0^{\mathrm{a}}$ & $21,0^{\mathrm{a}}$ & $29,0^{\mathrm{a}}$ & $34,5^{\mathrm{a}}$ & $29,5^{\mathrm{a}}$ & $28,0^{\mathrm{a}}$ & $26,3^{\mathrm{a}}$ \\
A6 & $9,7^{\mathrm{b}}$ & $10,5^{\mathrm{a}}$ & $20,3^{\mathrm{a}}$ & $30,5^{\mathrm{a}}$ & $40,3^{\mathrm{a}}$ & $35,7^{\mathrm{a}}$ & $35,2^{\mathrm{ab}}$ & $36,2^{\mathrm{a}}$ \\
Sig. & 0,00 & 0,33 & 0,63 & 0,135 & 0,58 & 0,082 & 0,029 & 0,079 \\
CV & 12,00 & 4,98 & 7,38 & 9,87 & 8,1 & 10,7 & 12,9 & 17,4 \\
\hline
\end{tabular}

Keterangan: Angka yang diikuti oleh huruf yang sama (huruf kecil vertikal) berbeda tidak nyata pada taraf $5 \%$ (Uji DMRT).

Tabel 9. Rata-rata coverage area pada berbagai umur pengamatan

\begin{tabular}{ccccc}
\hline \multirow{2}{*}{ Petak } & \multicolumn{4}{c}{ Coverage area pada umur (HST) } \\
\cline { 2 - 5 } & 21 & 28 & 35 & 42 \\
\hline A1 & $385,1^{\text {a }}$ & $1061,0^{\text {a }}$ & $1352,2^{\text {a }}$ & $1807^{\mathrm{a}}$ \\
A2 & $404,9^{\mathrm{a}}$ & $1019,0^{\mathrm{a}}$ & $1311,0^{\mathrm{a}}$ & $1953^{\mathrm{a}}$ \\
A3 & $345,3^{\mathrm{a}}$ & $938,0^{\mathrm{a}}$ & $1478,0^{\mathrm{a}}$ & $2098^{\mathrm{a}}$ \\
A4 & $355,5^{\mathrm{a}}$ & $877,0^{\mathrm{a}}$ & $1199,0^{\mathrm{a}}$ & $1545^{\mathrm{a}}$ \\
A5 & $339,3^{\mathrm{a}}$ & $983,7^{\mathrm{a}}$ & $1323,0^{\mathrm{a}}$ & $1711^{\mathrm{a}}$ \\
A6 & $279,1^{\mathrm{a}}$ & $767,8^{\mathrm{a}}$ & $1203,0^{\mathrm{a}}$ & $1841^{\mathrm{a}}$ \\
Sig, & 0,649 & 0,492 & 0,793 & 0,256 \\
CV & 12,34 & 11,28 & 7,91 & 10,47 \\
\hline
\end{tabular}

Keterangan: Angka yang diikuti oleh huruf yang sama (huruf kecil vertikal) berbeda tidak nyata pada taraf 5\% (Uji DMRT).

batang pada setiap petak tidak menunjukkan perbedaan nyata.

\section{Produktivitas Kedelai}

Pengukuran produktivitas tanaman kedelai dilakukan dengan cara mengambil biji pada setiap petak dengan ukuran $2 \mathrm{~m} \times 0,8 \mathrm{~m}$. Produktivitas tertinggi dihasilkan oleh petak $\mathrm{A} 2$ dengan nilai sebesar 3,84 ton/ha. Berdasarkan hasil uji Duncan (Tabel 11) menunjukkan bahwa produktivitas pada setiap petak memperlihatkan hasil yang berbeda nyata dengan nilai signifikansi 0,028 . Produktivitas kedelai sangat dipengaruhi oleh ketiga unsur hara makro yaitu nitrogen, fosfor dan kalium. Unsur kalium berfungsi
Tabel 10. Rata-rata diameter batang pada berbagai umur pengamatan

\begin{tabular}{cccccccc}
\hline \multirow{2}{*}{ Petak } & \multicolumn{7}{c}{ Diameter batang pada umur (HST) } \\
\cline { 2 - 8 } & 21 & 28 & 35 & 42 & 49 & 56 & 63 \\
\hline A1 & $0,2^{\mathrm{a}}$ & $0,4^{\mathrm{a}}$ & $0,4^{\mathrm{a}}$ & $0,4^{\mathrm{a}}$ & $0,4^{\mathrm{a}}$ & $0,4^{\mathrm{a}}$ & $0,4^{\mathrm{a}}$ \\
A2 & $0,3^{\mathrm{b}}$ & $0,4^{\mathrm{a}}$ & $0,4^{\mathrm{a}}$ & $0,4^{\mathrm{a}}$ & $0,5^{\mathrm{a}}$ & $0,5^{\mathrm{a}}$ & $0,5^{\mathrm{a}}$ \\
A3 & $0,3^{\mathrm{b}}$ & $0,4^{\mathrm{a}}$ & $0,4^{\mathrm{a}}$ & $0,5^{\mathrm{a}}$ & $0,5^{\mathrm{a}}$ & $0,5^{\mathrm{a}}$ & $0,5^{\mathrm{a}}$ \\
A4 & $0,2^{\mathrm{a}}$ & $0,3^{\mathrm{a}}$ & $0,4^{\mathrm{a}}$ & $0,4^{\mathrm{a}}$ & $0,4^{\mathrm{a}}$ & $0,4^{\mathrm{a}}$ & $0,4^{\mathrm{a}}$ \\
A5 & $0,2^{\mathrm{a}}$ & $0,3^{\mathrm{a}}$ & $0,4^{\mathrm{a}}$ & $0,4^{\mathrm{a}}$ & $0,4^{\mathrm{a}}$ & $0,5^{\mathrm{a}}$ & $0,5^{\mathrm{a}}$ \\
A6 & $0,3^{\mathrm{b}}$ & $0,4^{\mathrm{a}}$ & $0,4^{\mathrm{a}}$ & $0,4^{\mathrm{a}}$ & $0,4^{\mathrm{a}}$ & $0,5^{\mathrm{a}}$ & $0,5^{\mathrm{a}}$ \\
Sig, & 0,003 & 0,101 & 0,202 & 0,159 & 0,068 & 0,072 & 0,074 \\
CV & 8,82 & 6,2 & 5,69 & 6,04 & 6,85 & 6,45 & 6,57 \\
\hline
\end{tabular}

Keterangan: Angka yang diikuti oleh huruf yang sama (huruf kecil vertikal) berbeda tidak nyata pada taraf 5\% (Uji DMRT).

untuk memperkuat tanaman sehingga daun, bunga, dan buah tidak mudah rontok atau gugur serta salah satu sumber daya tahan tanaman terhadap kekeringan dan penyakit. Selain itu perbedaan hasil pada setiap petak diduga karena hama tanaman serta pencucian pupuk (leaching) karena irigasi. Serangan hama dapat menyebabkan penurunan hasil sampai $80 \%$, bahkan tanaman gagal menghasilkan apabila tidak ada upaya pengendalian hama (Marwoto, 1999).

Pemberian air tanaman dengan sistem irigasi (Gambar 5) membuat resiko leaching lebih tinggi. Kedelai pada lahan sawah tadah hujan yang ditanam pada Musim Kemarau 2 (Juni-Agustus) akan menghadapi permasalahan kekurangan air pada fase generatif 
Tabel 11. Bobot biji dan produktivitas kedelai pada setiap petak

\begin{tabular}{ccccccc}
\hline & \multicolumn{5}{c}{$\begin{array}{c}\text { Berat total biji } \\
\text { Petak }\end{array}$} & \multicolumn{9}{c}{ (g) } & $\begin{array}{c}\text { Rendemen } \\
(\%)\end{array}$ & $\begin{array}{c}\text { Produktivitas } \\
\text { (ton/ha) }\end{array}$ \\
\cline { 2 - 5 } & 1 & 2 & 3 & $\mathrm{x}$ & & $2,8^{\mathrm{ab}}$ \\
\hline A1 & 503 & 362 & 455 & 440,0 & 56,22 & $3,8^{\mathrm{c}}$ \\
A2 & 612 & 610 & 620 & 614,0 & 56,31 & $3,4^{\mathrm{c}}$ \\
A3 & 698 & 422 & 505 & 541,7 & 55,77 & $2,4^{\mathrm{a}}$ \\
A4 & 418 & 405 & 315 & 379,3 & 56,79 & $2,9^{\mathrm{ab}}$ \\
A5 & 459 & 432 & 502 & 464,3 & 57,47 & $2,9^{\mathrm{ab}}$ \\
A6 & 407 & 508 & 483 & 466,0 & 55,74 & 0,028 \\
Sig. & & & & & & 16,98 \\
CV & & & & & & \\
\hline
\end{tabular}

Keterangan: Angka yang diikuti oleh huruf yang sama (huruf kecil vertikal) berbeda tidak nyata pada taraf $5 \%$ (Uji DMRT).

apabila tidak ada suplai pengairan dari pompanisasi (air tanah) dan gangguan hama yang lebih berat (Subandi dkk., 2007). Pertumbuhan dan perkembangan tanaman kedelai sangat terhambat jika mengalami kekeringan dibandingkan dengan kedelai yang terpenuhi kebutuhan airnya (Anjum dkk., 2013).

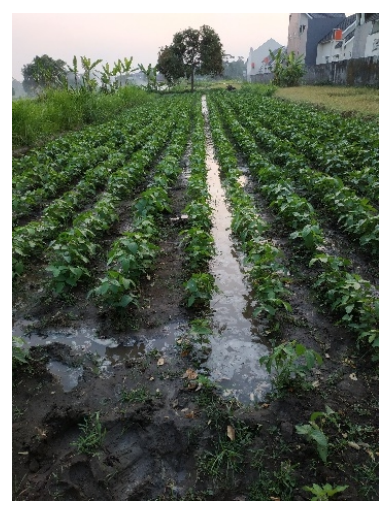

Gambar 5. Proses pengairan lahan

\section{Model Produktivitas Kedelai}

Produktivitas kedelai kemudian dimodelkan untuk memprediksikan hasil produktivitas yang diperoleh melalui data pertumbuhan kedelai dan penggunaan pupuk. Data pertumbuhan kedelai yang digunakan yaitu pada saat tanaman berumur 42 HST. Pengujian diawali dengan uji korelasi untuk melihat seberapa besar hubungan antara variabel sebagai dasar dalam menetukan parameter yang digunakan untuk membuat model produktivitas. Ada tiga cara yang dapat digunakan sebagai dasar dalam pengambilan keputusan yaitu jika nilai $r$ hitung (Pearson Correlation) $>r$ tabel $(0,632)$, nilai Sig. (2-tailed) $<0,05$ dan terdapat tanda bintang (*) maka terdapat korelasi antar variable.

Berdasarkan hasil uji korelasi (Tabel 12) dapat disimpulkan bahwa tinggi tanaman tidak memiliki korelasi dengan produktivitas karena nilai $r$ hitung lebih kecil dari nilai $r$ tabel $(-0,27<0,632)$. Pada parameter jumlah daun dan coverage area memiliki korelasi dengan produktivitas yang ditunjukkan dengan nilai $r$ hitung $>r$ tabel 0,816 dan 0,938. Sedangkan parameter diameter batang memiliki nilai $r$ hitung sebesar 0,61 sehingga memiliki hubungan yang kuat dengan variable produktivitas. Menurut Sujarweni (2014), nilai koefisien korelasi 0,41 sampai 0,70 memiliki hubungan yang kuat antara variable. Berdasarkan hasil uji korelasi, parameter-parameter yang digunakan dalam membuat model produktivitas yaitu jumlah daun, diameter batang dan coverage area. Berdasarkan hasil uji regresi linier berganda menggunakan SPSS didapatkan fungsi model Persamaan 4.

$Y=-2,603+0,019 P_{1}-0,389 P_{2}+0,198 P_{3}$

Dimana: $\mathrm{Y}$ adalah produktivitas (ton/ha), $\mathrm{P}_{1}$ adalah jumlah daun (helai), $\mathrm{P}_{2}$ adalah diameter batang $(\mathrm{cm})$, dan $\mathrm{P}_{3}$ adalah jari-jari coverage area $(\mathrm{cm})$.

Analisis regresis linier berganda selanjutnya yaitu analisis korelasi ganda $(R)$ dan analisis determinasi $\left(R^{2}\right)$ didapatkan nilai $R$ dan $R^{2}$ berturut-turut sebesar 0,949 dan 0,9. Menurut Sugiyono (2007), nilai R yang berkisar $0,8-1,0$ menunjukkan hubungan yang kuat antara variabel independen terhadap variabel dependen. Hal ini menunjukkan bahwa terjadi hubungan yang sangat 
Tabel 12. Uji korelasi pada parameter pertumbuhan dan produktivitas kedelai

\begin{tabular}{llrrrrr}
\hline & & Tinggi & \multirow{2}{*}{$\begin{array}{c}\text { Jumlah } \\
\text { daun }\end{array}$} & $\begin{array}{c}\text { Diameter } \\
\text { batang }\end{array}$ & \multicolumn{2}{c}{ Coverage } \\
\cline { 6 - 7 } Produktivitas & & Pearson correlation & $-0,27$ & 0,816 & 0,61 & 0,938 \\
& Sig. (2-tailed) & 0,456 & 0,004 & 0,061 & 0 \\
\hline
\end{tabular}

kuat antara jumlah daun, diameter batang dan coverage area terhadap produktivitas. Nilai $\mathrm{R}^{2}$ yang didapatkan sebesar 0,9 menunjukkan bahwa persentase pengaruh variable independen (jumlah daun, diameter batang dan coverage area) terhadap variable dependen sebesar $90 \%$. Pada Gambar 6 menunjukkan hubungan antara produktivitas (real) terhadap prediksi produktivitas berdasarkan fungsi model yang dibangun didapatkan nilai $R^{2}$ sebesar 0,84 .

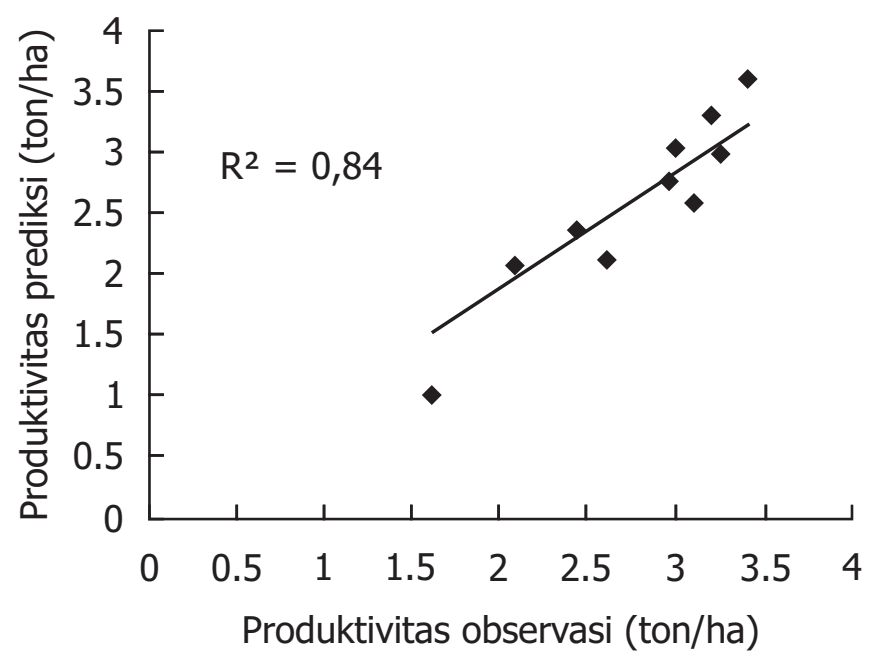

Gambar 6. Validasi model produktivitas kedelai dengan variabel pertumbuhan tanaman

Model produktivitas terhadap penggunaan pupuk dianalisis menggunakan regresi non linier model kuadratik. Regresi nonlinear model kuadratik merupakan suatu metode untuk mendapatkan model linier yang menyatakan hubungan antara dua peubah yang terdiri dari variabel dependen $(Y)$ dan variabel independen $(X)$. Pada kasus ini, yang menjadi variabel dependen $(Y)$ adalah produktivitas kedelai, dan yang menjadi variabel independen $(X)$ adalah pupuk urea $\left(X_{1}\right)$, SP-36 $\left(X_{2}\right)$ dan $\mathrm{KCl}\left(\mathrm{X}_{3}\right)$.

Pemodelan dengan variabel independen pupuk urea $\left(X_{1}\right)$ tidak dapat dianalisis karena variasi pupuk yang digunakan hanya 1 variasi. Hasil uji regresi non linier dengan variabel independen pupuk SP36 diperoleh nilai koefisien korelasi $(R)$ dan koefisien determinasi $\left(R^{2}\right)$ berturut-turut sebesar 0,762 dan 0,581 . Berdasarkan nilai $\mathrm{R}$ tersebut, menunjukkan bahwa hubungan jumlah penggunaan pupuk SP-36 terhadap produktivitas memiliki korelasi yang kuat. Nilai $R^{2}$ sebesar 0,581 menunjukkan bahwa persentase pengaruh variabel pupuk SP-36 terhadap produktivitas sebesar 58,1\%. Berdasarkan hasil regresi non linier didapatkan Persamaan 5.

$Y=-1,405.10^{-4}+0,12 X_{2}-0,001 X_{2}^{2}$

Berdasarkan analisis regresi linier model kuadratik hubungan antara pengaruh dosis SP-36 dengan produktivitas kedelai, diperoleh grafik pada Gambar 7.

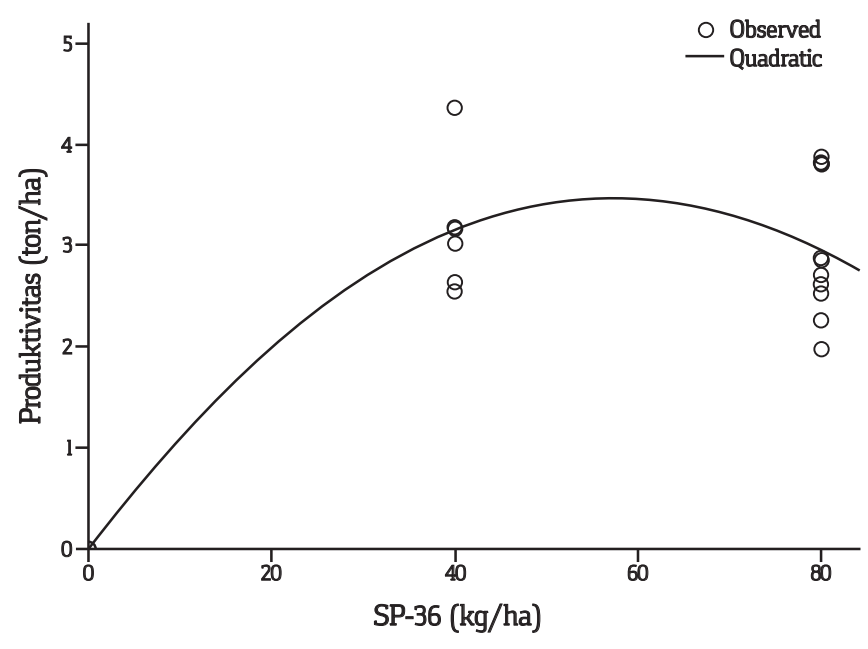

Gambar 7. Hubungan dosis SP-36 terhadap produktivitas

Hasil uji regresi non linier dengan variabel independen pupuk $\mathrm{KCl}$ diperoleh nilai koefisien korelasi (R) dan koefisien determinasi $\left(R^{2}\right)$ berturut-turut sebesar 0,837 dan 0,701. Berdasarkan nilai $R$ tersebut, menunjukkan bahwa hubungan dosis $\mathrm{KCl}$ terhadap produktivitas kedelai memiliki korelasi yang sangat kuat. Nilai $R^{2}$ sebesar 0,701 menunjukkan bahwa persentase pengaruh variabel pupuk $\mathrm{KCl}$ terhadap produktivitas kedelai sebesar $70,1 \%$. Berdasarkan hasil regresi non linier didapatkan Persamaan 6.

$Y=-2,546 \cdot 10^{-16}+0,053 X_{3}-2,063 \cdot 10^{-4} X_{3}^{2}$

Berdasarkan analisis regresi linier model kuadratik hubungan antara pengaruh penggunaan pupuk $\mathrm{KCl}$ 
dengan produktivitas kedelai, diperoleh grafik yang ditampilkan pada Gambar 8. Hasil regresi non linier pada pupuk SP-36 dan $\mathrm{KCl}$ memiliki nilai $\mathrm{R}^{2}$ diatas 0,5 atau berpengaruh sebesar $50 \%$ terhadap produktivitas sedangkan sisanya sebesar $50 \%$ disumbangkan oleh variabel lain di luar penelitian ini. Faktor produksi yang lain juga dapat mempengaruhi produktivitas, antara lain luas lahan, jumlah pupuk, jumlah pestisida, iklim dan sistem irigasi (Arizka, 2019).

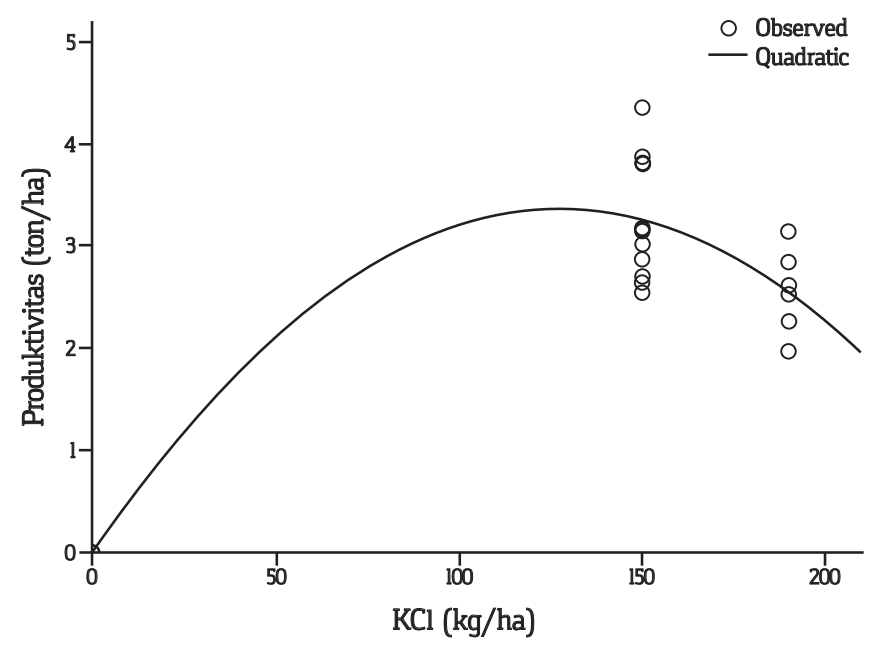

Gambar 8. Hubungan antara dosis $\mathrm{KCl}$ terhadap produktivitas kedelai

\section{KESIMPULAN}

Berdasarkan hasil pengujian alat pemupuk di lapangan diperoleh kapasitas lapang efektif (KLE), kapasitas lapang teoritis (KLT) dan efisiensi lapang (Ef) berturut-turut sebesar $624 \mathrm{~m}^{2} / \mathrm{jam}, 864 \mathrm{~m}^{2} / \mathrm{jam}$, dan $72,27 \%$. Dari hasil analisis pertumbuhan tanaman menunjukkan bahwa secara statistik pemberian pupuk menggunakan aplikator tidak secara signifikan mempengaruhi parameter tinggi tanaman tetapi secara signifikan berpengaruh nyata terhadap diameter batang, jumlah daun, dan coverage area. Meskipun demikian masih dijumpai ketidakseragaman produktivitas tanaman kedelai yang ditunjukkan dengan nilai signifikansi sebesar 0,028 sehingga memerlukan kajian lebih lanjut. Hasil uji regresi linier berganda antara variabel pertumbuhan $(\mathrm{P} 1$ jumlah daun, P2 diameter batang, P3 coverage area) dengan produktivitas didapatkan fungsi $Y=-2,603+$ $0,019 P_{1}-0,389 P_{2}+0,198 P_{3}$ dengan nilai $R^{2}$ sebesar 0,84 . Analisis regresi non linier dengan variabel SP36 (X2) terhadap produktivitas didapatkan fungsi $\mathrm{Y}=$ $-1,405.10^{-4}+0,12 X_{2}-0,001 X_{2}^{2}$ dengan nilai $R^{2}$ sebesar 0,581 . Analisis regresi dengan variabel $\mathrm{KCl}(\mathrm{X} 3)$ terhadap produktivitas didapatkan fungsi $Y=-2,546.10^{-16}+$ $0,053 X_{3}-2,063 \cdot 10^{-4} X_{3}^{2}$ dengan nilai $R^{2}$ sebesar 0,701 .

\section{UCAPAN TERIMA KASIH}

Ucapan terima kasih disampaikan kepada Direktorat Penelitian dan Pengabdian Masyarakat, Kementerian Riset, Teknologi dan Pendidikan Tinggi, Republik Indonesia atas dukungan Hibah Penelitian Tesis Magister Tahun 2019 untuk membiayai penelitian ini. Ucapan terima kasih juga disampaikan kepada semua pihak yang telah berkontribusi dalam penelitian ini. Publikasi ini adalah bagian dari Penelitian Tesis di Program Magister Teknik Pertanian, Fakultas Teknologi Pertanian, UGM.

\section{KONFLIK KEPENTINGAN}

Tidak ada konflik kepentingan terkait dengan naskah ini.

\section{DAFTAR PUSTAKA}

Anjum, S. A., Ehsanullah, Xue, L., Wang, L., Saleem, M. F., \& Huang, C. J. (2013). Exogenous benzoic acid (BZA) treatment can induce drought tolerance in soybean plants by improving gas-exchange and chlorophyll contents. Australian Journal of Crop Science, 7(5), 555560.

Arizka, A. A. (2019). Kajian Penerapan Mekanisasi Pertanian Berbasis Usaha Pelayanan Jasa Alat dan Mesin Pertanian (UPJA) untuk Sistem Produksi Padi di Kabupaten Banyumas, Purbalingga dan Banjarnegara. In Universitas Gadjah Mada.

Azis. S, A., A. Setiawan, R., \& Subrata, I. (2011). Disain dan Pengujian Metering Device untuk Alat Penjatah Pupuk Granular Laju Variabel (Variable Rate Granular Fertilizer Applicator). Jurnal Keteknikan Pertanian, 25(2), 79-85.

Balai Penelitian Tanah (BPT). (2007). Perangkat Uji Tanah Kering V.01 (Upland Soil Test Kit). In Balai Besar Penelitian dan Pengembangan Sumberdaya Lahan Pertanian Badan Penelitian dan Pengembangan Pertanian Departemen Pertanian. https://doi.org/10.22302/ppk.jpk.v1i1.304

Fuadi, M., Sutiarso, L., Radi, Virgawati, S., \& Nugraheni, P. H. T. (2019). Design of liquid fertilizer applicator based on Variable Rate Application (VRA) for Soybean. IOP Conference Series: Earth and Environmental Science, 355(1). https:// doi.org/10.1088/1755-1315/355/1/012009

Horneck, D. A., Sullivan, D. M., Owen, J. S., \& Hart, J. (2011). Soil Test Interpretation Guide. In Rehabilitation (Issue 3, pp. 1-8). https://doi.org/10.1017/CBO9781107415324.004

Marwoto. (1999). Rakitan teknologi PHT pada tanaman kedelai. Prosiding Lokakarya Strategi Pengembangan Produksi 
Kedelai, 67-97. http://www.ejurnal.litbang.pertanian. go.id/index.php/ippan/article/download/2598/2238

Musaddad, A. (2008). Teknologi produksi kedelai, kacang tanah, kacang hijau, ubi kayu, dan ubi jalar. Balai Penelitian Kacang- kacangan dan Umbi-umbian.

Parnata, A. S. (2010). Meningkatkan Hasil Panen dengan Pupuk Organik. PT. Agro Media Pustaka.

Permadi, K., \& Haryati, Y. (2015). Pemberian Pupuk N, P, dan K Berdasarkan Pengelolaan Hara Spesifik Lokasi untuk Meningkatkan Produktivitas Kedelai (Review). Agrotrop: Journal on Agriculture Science, 5(1), 1-8.

Rahutomo, S., \& Ginting, E. (2018). Tingkat Pencucian N, P, $K$, dan Mg dari Aplikasi Beberapa Jenis Pupuk Leaching Level of $N, P, K$, and Mg from Application of. 26(1), $37-47$.

Srihartanto, E., Anshori, A., \& Iswandi, A. (2015). Produktivitas Kedelai dengan Berbagai Jarak Tanam di Yogyakarta. Prosiding Seminar Hasil Penelitian Tanaman Aneka Kacang dan Umbi 2015, 22, 151-154.

Subandi, Harsono, A., \& Kuntyastuti, H. (2007). Areal Pertanaman dan Sistem Produksi Kedelai di Indonesia. Kedelai: Teknik Produksi Dan Pengembangan, 104129. http://balitkabi.litbang.pertanian.go.id/publikasi/ monograf/kedelai-teknik-produksi-dan-pengembangan/
Sugiyono. (2007). Metode Penelitian Bisnis. In Bandung: CV. Alfabeta. https://doi.org/10.26555/jiteki.v3i2.7479

Sujarweni, V. W. (2014). SPSS untuk Penelitian. Pustaka Baru Press.

Sumarno. (1995). Identifikasi Teknologi Usahatani Kedelai. Balai Penelitian Tanaman Pangan Malang. https://doi. org/10.22146/agritech.38497

Wahyudin, A., Ruminta, R., \& Bachtiar, D. C. (2015). Pengaruh jarak tanam berbeda pada berbagai dosis pupuk organik terhadap pertumbuhan dan hasil jagung hibrida P-12 di Jatinangor. Jurnal Kultivasi, 14(1), 1-8. https://doi. org/10.24198/kltv.v14i1.12097

Whelan, B., \& Taylor, J. (2013). Precision Agriculture for Grain Production Systems. CSIRO Publishing, ISBN: 978-. https://media.neliti.com/media/publications/123270ID-none.pdf

Yamani, A. (2012). Analisis Kadar Hara Makro Tanah pada Hutan Lindung Gunung Sebatung di Kabupaten Kotabaru. Jurnal Hutan Tropis, 12(2), 181-187. 